\title{
Effect of brief interventions in reducing hazardous alcohol consumption in users receiving methadone treatment
}

\author{
Efeito das intervençóes breves na redução do consumo de risco nos utentes em tratamen- \\ to com metadona \\ Efecto de las intervenciones breves para reducir el consumo de riesgo de los usuarios en \\ tratamiento con metadona
}

Nídia Raquel Pereira Rosa*; Ângela Maria Mendes Abreu**; Teresa Maria Mendes Diniz de Andrade Barroso ${ }^{* * *}$

\begin{abstract}
Theoretical framework: Alcohol consumption in individuals receiving methadone treatment can be a problem for treatment stability and adherence.

Objectives: To assess the effect of Brief Interventions in reducing hazardous risk consumption in users receiving methadone treatment

Methodology: Pre-experimental study, with one-group pretest-posttest design. Non-randomised consecutive sample of 24 users. The Alcohol Use Disorders Identification Test (AUDIT) was used. Brief interventions were performed by nurses with specific training.

Results: At baseline, 16 subjects had a low risk, 6 had a hazardous risk, and 2 had a harmful risk. In the final assessment, 5 months after the Brief Interventions, 19 subjects had a low risk and 5 a hazardous risk. No cases were found of harmful drinking. A statistically significant reduction in the drinking risk levels was observed $(p=.031)$.

Conclusion: The results suggest positive effects of Brief Interventions in reducing hazardous alcohol in users receiving methadone treatment.
\end{abstract}

Keywords: heroin dependence; methadone; alcoholic beverages; nursing.

\section{Resumo}

Enquadramento: O consumo de álcool nos indivíduos em tratamento com metadona pode constituir um problema para a estabilidade e a adesão ao tratamento.

Objectivos: Avaliar o efeito das Intervenções Breves (IB) na redução do consumo de risco, nos utentes em tratamento com metadona

Metodologia: Estudo de natureza pré-experimental, avaliação antes e após com grupo único. Amostra não aleatória, consecutiva de 24 utentes. Inclui o Alcohol Use Disorders Identificacion Test (AUDIT). As Intervenções breves foram desenvolvidas pelo enfermeiro com treino específico.

Resultados: Na avaliação inicial, 16 sujeitos apresentavam nível de baixo risco, 6 nível de risco e 2 nível nocivo. Na avaliação final, 5 meses após as IB, 19 sujeitos apresentavam nível de baixo risco, 5 nível de risco e nenhum caso com consumo nocivo, verificandose uma redução dos níveis de risco tendo sido a evolução estatisticamente significativa $(p=0,031)$.

Conclusão: Os resultados sugeriram efeitos positivos das IB na diminuição do consumo de risco dos utentes em tratamento com metadona.

Palavras-chave: dependência de heroína; metadona; bebidas alcoólicas; enfermagem.

\footnotetext{
* MSc, RN, Centre for Integrated Responses of Coimbra - Treatment Team of Figueira da Foz, Portugal [nidia.rosa@arscentro.min-saude.pt]. Contribution to the article: bibliographic search; experimentation; data collection; statistical treatment and evaluation; data analysis and discussion; article writing. Address for correspondence: Rua do Covão - Casalinhos, 3080-153, Figueira da Foz, Portugal.

** PhD Adjunct Professor, Nursing Department of Public Health, Anna Nery School of Nursing 20.211-110, Rio de Janeiro, Brazil [angelabreu@golbo.com]. Contribution to the article: article writing and revision.

*** Ph.D., Adjunct Professor, Health Sciences Research Unit: Nursing, Nursing School of Coimbra, 3046-851, Coimbra, Portugal [tbarroso@esenfc.pt]. Contribution to the article: study design; methodological follow-up; statistical treatment and evaluation; data analysis and discussion; article writing and revision.
}

\section{Resumen}

Marco contextual: El consumo de alcohol en los individuos tratados con metadona puede ser un problema para la estabilidad y la adhesión al tratamiento.

Objetivos: Evaluar el efecto de las intervenciones breves para reducir el consumo de riesgo de los usuarios que están en tratamiento con metadona.

Metodología: Estudio de naturaleza preexperimental, evaluación antes y después de las intervenciones con un grupo único. Muestra no aleatoria y consecutiva de 24 usuarios. Incluye el Alcohol Use Disorders Identificacion Test (AUDIT). Las intervenciones breves fueron realizadas por enfermeros con una formación específica.

Resultados: En la evaluación inicial, 16 sujetos presentaron un nivel de riesgo bajo, 6 nivel de riesgo y 2 nivel nocivo. En la evaluación final, 5 meses después de las intervenciones breves, 19 sujetos presentaron un nivel de riesgo bajo, 5 nivel de riesgo y no hubo casos con nivel de consumo nocivo, lo que verifica una reducción de los niveles de riesgo y una evolución estadísticamente significativa $(p=0,031)$.

Conclusión: Los resultados sugirieron efectos positivos de las intervenciones breves en la disminución del consumo de riesgo de los pacientes que están en tratamiento con metadona.

Palabras clave: dependencia de heroína; metadona, bebidas alcoholicas, enfermería.

Received for publication: 21.11.14

Accepted for publication: 02.07 .15 


\section{Introduction}

The behaviours related to the use of psychoactive substance are an important risk factor for individuals and societies worldwide. Alcohol use was identified as a major risk factor, causing several diseases and premature death worldwide, particularly in the European Region (World Health Organization, 2014). Alcohol use in individuals in a methadone maintenance treatment program may be a serious problem for stability and treatment adherence. Since the 1990s, studies in this area indicate that one-third or more of individuals receiving treatment with hydrochloride methadone consumed alcohol on a regular basis (ElBassel, Schilling, Turnbull, \& Kuo-Hsien, 1993). On the other hand, the results of studies conducted in this area indicate that the problematic use of alcohol is associated with several risk behaviours, such as sharing needles and using psychoactive substances (El-Bassel et al., 1993). Other studies suggest that alcohol consumption decreases after admission to the treatment program (Caputo et al., 2002).

From another perspective, a high rate of alcohol abuse was observed among users in a methadone program in comparison with the general population. An increase in alcohol consumption during the methadone treatment was also observed, which may be related to the compensatory effect of alcohol in combination with methadone, based on the previous heroin use (Ottomanelli, 1998). Despite the fact that early detection and appropriate interventions are essential, healthcare professionals have not adequately managed alcohol-related problems in individuals undergoing methadone treatment maintenance programs (Moussas et al., 2015).

With regards to alcohol-related problems, there is scientific evidence to suggest that healthcare professionals should raise the awareness of the general population through universal prevention programs, as well as through the use of brief interventions (BIs) directed to primary health care with the aim of detecting and intervening early to reduce hazardous and harmful alcohol consumption (Furtado \& Marques, 2004; Barroso, Barbosa, \& Mendes, 2006; Segatto, Pinky, Laranjeira, Rezende, \& Vilela, 2007).

Thus, other authors suggest that BIs have the best cost/benefit ratio for hazardous and harmful consumption (Furtado \& Marques, 2004; Ribeiro, 2014). The effectiveness of these interventions is overall associated with the set of best practices developed by qualified healthcare professionals (Schaus, Sole, McCoy, Mullett, \& O'Brien, 2009; Seigers \& Carey, 2010).

In Portugal, there are few studies on the effects of BIs in reducing hazardous alcohol consumption and no studies were found that assessed the effects of these interventions in this population. The aim of this study was to assess the effect of BIs in reducing hazardous alcohol consumption in users receiving methadone treatment.

\section{Background}

Harmful alcohol use is a threat to public health worldwide. According to the WHO report, alcohol is a causal factor in around 60 types of diseases. It also has many other consequences, including: accidents at work, maternal, child and family health disorders, organic pathology (the chronic diseases affecting the individuals after several years of alcohol abuse and the effects related to acute consumption) and associated care/treatment (World Health Organization, 2014). The use of psychoactive substances is an important risk factor for individuals and societies worldwide. The World Health Report 2002 indicated that 8.9\% of the total burden of disease comes from the use of these substances, and that alcohol accounted for $4 \%$ and illicit drugs $0.8 \%$ of the burden of disease (Segato et al., 2007). Every year, alcohol causes 1.8 million deaths $(3.2 \%$ of total) and a loss of 58.3 million ( $4 \%$ of total) disability-adjusted life years worldwide (World Health Organization, 2014).

The 2007 Portuguese General Population Survey on Psychoactive Substance Use showed an increase in the prevalence of substance use in all age groups. Between 2001 and 2007, the prevalence of alcohol consumption increased by $3.5 \%$, from $75.6 \%$ to $79.1 \%$. The percentage of the population who started to drink alcoholic beverages between 15 and 17 years of age was approximately $30 \%$ in 2001 , increasing to 40\% in 2007 (Balsa, Vital, Urbano, \& Pascueiro, 2008). In relation to problem recognition, in Portugal, data for 2011 indicate that 45863 users were treated for illicit substance and/or alcohol use in specialised public services (Serviço de Intervenção nos Comportamentos Aditivos e nas Dependências [SICAD], 2013). In 2011, 21236 people entered 
opiate agonist maintenance programs (methadone and buprenorphine), of whom $78 \%$ underwent a methadone treatment program (Instituto de Droga e da Toxicodependência [IDT], 2012).

Opiate agonist maintenance programs, particularly with methadone, are deemed to be effective, as they keep users in treatment, reducing heroin use and associated problems, health complications, and crime rates. However, many of these users continue to use other substances, particularly alcohol, despite its adverse consequences. One of the most important concerns related to alcohol consumption during the methadone maintenance therapy is the increase of the depressive effect of methadone in the Central Nervous System, namely depression of the respiratory centre and the consequent clinical implications (Patrício, 2009).

As mentioned above, some studies on alcohol consumption patterns in users undergoing methadone maintenance programs indicate an increase in alcohol consumption during these programs, probably due to the compensatory effect of alcohol associated with the methadone doses used in the treatment (Caputo et al., 2002).

In Portugal, in a study on the consumption patterns of users in agonist treatment programs, the authors found that, among the sampled individuals $(n=39)$, 23.1\% of the users had hazardous levels for alcohol used (assessed with the AUDIT) and 28.2\% were dependent on alcohol (Henriques \& Paixão, 2009).

This study was conducted by a Treatment Team (TT) of a Centre for Integrated Responses at a local intervention unit which has the purpose of intervening in situations of harmful consumption, moderate dependence, and polyconsumption. These local units were restructured at the end of 2011, after the decision to extinguish by merger the Institute on Drugs and Drug Addiction, IP (Instituto da Droga e da Toxicodependência - IDT), and integrated it into the General Directorate for Intervention on Addictive Behaviours and Dependencies and the Regional Health Administrations, IP. The Reference Network was also part of this restructuring process. This Network calls for different levels of intervention, namely interventions for screening and early detection of hazardous and harmful consumption and dependence, as well as BIs.

BIs are simple procedures based on cognitivebehavioural assumptions, directed towards the patients' education and motivation to change behaviours. They are low in cost and proved to be effective in reducing alcohol consumption and alcohol-related problems (Babor \& Higgins-Biddle, 2001; Barroso, Rosa, Jorge, \& Gonçalves, 2012). Nurses are in a unique position to assess and implement BIs in the various contexts of their practice.

\section{Research Question}

Individuals undergoing Bis reduce hazardous drinking.

\section{Methodology}

This is a pre-experimental study, with one-group pretest-posttest design. The participants in this study were users of a TT addicted to illicit psychoactive substances and undergoing methadone maintenance treatment. At baseline, the sample was composed of 25 users undergoing a methadone maintenance treatment program (19 men and six women).

As regards the results on the effect of BIs, considering the variable 'risk levels of alcohol consumption' (based on the AUDIT and the characteristics of the intervention), it should be noted that it was only possible to assess 24 of the respondents in the final assessment, which was our final sample.

This is a nonprobability consecutive sample composed of all users in the treatment team who accepted and gave their informed consent to participate in the study during a specific period (the month of November), taking into account the following inclusion criteria: addicted to illicit psychoactive substances, receiving methadone treatment, without a diagnosis of alcohol dependence, knowing how to read and write, aged 18 years or more.

Pre-test assessment, screening and BIs were performed in November 2011, whereas the post-test (5 months later) occurred in April 2012, with a view to assessing the risk levels of alcohol consumption.

The instrument used was a 2-part questionnaire. The first part related to sociodemographic questions, psychoactive substance use, alcohol consumption, and treatments underwent by the users. The second part included the Alcohol Use Disorders Identification Test (AUDIT), a questionnaire globally recognised as a 
screening instrument developed by the World Health Organization with the purpose of identifying people with hazardous and harmful drinking in services of different levels and contexts.

The AUDIT measures consumption, addiction symptoms, and the personal and social consequences of drinking. The questionnaire addresses the consumption pattern and its consequences in the last 12 months and contains ten questions: the first three assess the quantity and frequency of alcohol use, and binge drinking; the next three, dependence symptoms; and the final four, the risk of harmful consequences for the user. The AUDIT emphasises the identification of harmful drinking and adverse consequences and focuses mainly on the symptoms that occurred over the last 12 months (Babor \& Higgins-Biddle, 2001). Its use is recommended by the National Plan on Addictive Behaviours and Dependencies (SICAD, 2013).

The AUDIT scores range from 0 to 4 , with higher scores indicating problems. The AUDIT allows assessing three different levels of risk: level I (0-7), low risk; level II (8-15), hazardous risk; level III (16-19), harmful risk; level IV (>20), probable dependence. A score of 7 or less indicates a low likelihood of binge drinking; a score of 8-15 (level II) corresponds to hazardous drinking. Hazardous drinking is a level or pattern of alcohol use that leads to harmful health consequences, if consumption continues, and may not be visible. Scores between 16 and 19 (level III) correspond to harmful drinking, which is defined as a pattern of alcohol use with consequences on the physical health (e.g., liver cirrhosis), mental health (e.g., depression), and sociofamily health (e.g., accidents at work or violence) (Babor \& HigginsBiddle, 2001).

The medical history of people with harmful drinking should be taken (including traumatic events), and any physical signs associated with consumption should be analysed. A BI and follow-up should also be provided. In the presence of symptoms and/or signs of alcoholrelated problems, complementary tests should be performed. The presence of alcohol dependence should also be assessed (Babor \& Higgins-Biddle, 2001).

The following variables were used in this study: sociodemographic variables (gender, age, profession, place of birth, residence, education, and living arrangements), an independent variable (the
BIs: Alcohol Education, Simple Advice, and Brief Counselling) and a dependent variable (risk levels of alcohol consumption).

BIs were developed by a specifically trained nurse (Training and acquisition of skills for protocol implementation). BIs were implemented based on the levels of risk and the protocol adapted from Babor and Higgins-Biddle (2001). Users with low risk (level I; score 0-7) received an educational intervention; users with hazardous risk (level II; score 8-15) received simple advice; users with harmful risk (level III; score 16-19) received simple advice and brief counselling; and users with levels of risk IV (20-40) were referred to diagnostic evaluation.

Different scripts were designed for each BI in each level of risk, taking into consideration certain aspects, such as language and the respective approach.

BIs were developed based on structured scripts adapted from Babor and Higgins-Biddle (2001) within the scope of the project Saude sem Reservas of the Health Sciences Research Unit: Nursing.

Twenty-five BIs were developed during this study: 16 Educational Interventions, 6 Simple Advice Interventions, and 2 Brief Counselling Interventions. Data were analysed using the Statistical Package for the Social Sciences (SPSS), version 17. Data were processed and analysed using the Shapiro-Wilk test to check for normality of distribution. Considering the results of the Shapiro-Wilk normality tests (for a sample with less than 50 subjects), the dependent variables call into question the assumptions of normality. Taking into account the type of study variable (risk levels for alcohol consumption) and the type of sample (paired sample), the non-parametric Wilcoxon test was used to assess the effect of BIs on the sample.

All participants were previously informed about the study and relevant doubts were clarified. These aspects were ensured by a free and informed consent. The study was approved by the Regional Delegation of the Centre of the IDT, IP.

\section{Results}

The sample was initially composed of 25 users in a methadone maintenance treatment program $(76.0 \%$ were men and $24.0 \%$ were women), with a mean age of 37.2 years $(S D=6.7)$. The sample was characterised 
based on sociodemographic variables, psychoactive substance use, alcohol consumption, and treatments underwent by the users. Approximately $64.0 \%$ of the sampled individuals were unemployed and $84.0 \%$ of the respondents lived with their family, as shown in Table 1.

Table 1

Sample characterisation according to sociodemographic variables. Coimbra / Portugal $(n=25)$

\begin{tabular}{|c|c|c|c|}
\hline \multicolumn{2}{|c|}{ Sociodemographic characteristics } & \multicolumn{2}{|c|}{ Sample $(n=25)$} \\
\hline & & Mean & SD \\
\hline \multicolumn{2}{|c|}{ Age } & 37.2 & 6.7 \\
\hline \multirow[b]{4}{*}{ Emplovment situation } & & $\mathrm{n}$ & $\%$ \\
\hline & Male & 19 & 76.0 \\
\hline & Female & 6 & 24.0 \\
\hline & Employed & 7 & 28.0 \\
\hline \multirow{2}{*}{ Employment situation } & Unemployed & 16 & 64.0 \\
\hline & Retired & 2 & 8.0 \\
\hline \multirow{4}{*}{ Level of education } & Primary education & 1 & 4.0 \\
\hline & $6^{\text {th }}$ grade & 9 & 36.0 \\
\hline & $9^{\text {th }}$ grade & 9 & 36.0 \\
\hline & $12^{\text {th }}$ grade & 6 & 24.0 \\
\hline \multirow[t]{4}{*}{ Living arrangements } & Family & 21 & 84.0 \\
\hline & Alone & 2 & 8.0 \\
\hline & Friends & 2 & 8.0 \\
\hline & & - & - \\
\hline
\end{tabular}

Considering the evolution of the 24 users of the sample (before and after the BIs), as can be seen in Table 2, at baseline, $68.0 \%$ of users were in level I and at the final assessment there was an increase to $79.2 \%$ in this low risk level; at baseline, $24.0 \%$ of users were in the hazardous risk level (II),but , after the BIs, the number of users at this level of risk decreased (20.8\%); at baseline, 2 users were in the harmful risk level, but, in the final assessment, no user was at that level.

Table 2

Comparison of the sample based on the levels of risk before and after the Brief Interventions. Coimbral Portugal. $(N=24)$

\begin{tabular}{lllll}
\hline & \multicolumn{2}{l}{ Baseline Assessment $(\mathrm{n}=24)$} & \multicolumn{2}{l}{ Final Assessment $(\mathrm{n}=24)$} \\
\cline { 2 - 5 } & $\mathrm{N}$ & $\%$ & $\mathrm{~N}$ & $\%$ \\
Level I $(0-7)$ & 16 & 66.7 & 19 & 79.2 \\
Level II $(8-15)$ & 6 & 25.0 & 5 & 20.8 \\
Level II $(16-19)$ & 2 & 8.3 & 0 & 0 \\
\hline
\end{tabular}

Five users reduced their risk of alcohol consumption. In this sample, none of the users increased the level of risk, and 19 users maintained the level of risk (between low risk and hazardous risk) which indicated a positive and statistically significant effect on risk levels $(\mathrm{z}=-2.236 ; p=.031)$. 


\begin{tabular}{lcccc}
\hline & Positions & Frequencies & $\mathrm{Z}$ & $\mathrm{P}$ \\
\cline { 2 - 5 } Final level of risk * Baseline level of risk & Negative & $5^{\mathrm{a}}$ & & \\
$(\mathrm{n}=24)$ & Positive & $0^{\mathrm{b}}$ & -2.236 & 0.031 \\
& Ties & $19^{\mathrm{c}}$ & & \\
\hline
\end{tabular}

Note:

${ }^{\mathrm{a}}$ Final level of risk $<$ Baseline level of risk, ${ }^{\mathrm{b}}$ Final level of risk $>$ Baseline level of risk

${ }^{c}$ Final level of risk $=$ Baseline level of risk

\section{Discussion}

After analysis of the results on the user's profile, we concluded that the sample was composed of young adults with a mean age of 37.2 years, mostly men, unemployed, living with the family, and with a low level of education. These results are consistent with the data collected in the national reports, as shown in the study by the IDT, IP (2012). In 2011, the users who used the outpatient units were mostly men (82.8\%), with a mean age of 39 years, of Portuguese nationality and single (58.3\%), living with the family (48.4\%), and with a low level of education ( $61.4 \%$ with less than the $9^{\text {th }}$ grade).

As regards the levels of risk I, II and III before and after the BIs, this study showed significant results related to a change of behaviour in these individuals, which is clear in the migrations of these users to lower levels of risk. As can be seen in these results, five individuals reduced their level of risk and 19 maintained their level of risk. These differences were statistically significant and suggest a positive effect of BIs in reducing harmful alcohol consumption. These results suggest that BIs contribute to reducing and/or stabilising the levels of risk of alcohol consumption and reinforce the results of other studies in this area. Studies such as the ones by Schaus, Sole, McCoy, Mullett, and O'Brien (2009) and Seigers and Carey (2010) suggest that BIs have a significant effect in reducing alcohol consumption and associated problems. They also report that these interventions have been used as a reference to both refer harmful drinkers to treatment and reduce alcohol consumption (Schaus et al., 2009).

The main purpose of these interventions is to detect the problem and motivate people to change behaviours. Furthermore, they aim at identifying individuals at risk for alcohol consumption, individuals who already have problems or even cases of alcohol dependence (Furtado \& Marques, 2004). In addition, they provide healthcare professionals with information to develop tailored intervention plans, which can be used to motivate behaviour change, triggering the decision and the commitment to change (Segato et al., 2007).

The effectiveness of BIs is associated with the set of good practices undertaken by healthcare professionals who have received specific training in this area. After the identification of consumption, the BIs correspond, in terms of evidence, to the most effective type of approach in the context of hazardous and harmful consumption in Primary Health Care (Ribeiro, 2014).

These interventions have several advantages, such as the fact that they are easily included in nursing appointments, are quickly applied, use didactic material, and consist of a short sequence of steps (Furtado \& Marques, 2004; Schaus et al., 2009; Seigers \& Carey, 2010). These steps included the identification and extent of problems or risks, advice and counselling and, in some situations, regular monitoring of the accomplishment of the objectives voluntarily assumed by the individual.

Alcohol consumption among these users is a concern to healthcare professionals who promote healthy behaviours during methadone maintenance treatment programs. The use of methadone and alcohol in individuals undergoing these programs can have serious implications. The concerns with this dual consumption relate to the increase of the depressive effect on the central nervous system, with the effects resulting from hepatic enzyme induction, and can be a serious threat to stability and treatment adherence (Patrício, 2009).

For alcohol dependence not to be seen as one more problem associated with the sample of this study, 
further studies should be conducted focusing on prevention, Primary Health care, detection, and early interventions. Moreover, the benefits of using BIs to reduce alcohol consumption among the population in methadone maintenance treatment programs should also be highlighted (Gossop, Marsden, \& Stewart, 2002).

A limitation of this study was related to the researcher's barriers as she had to adapt her intervention both as responsible for the study and as a nurse working at the unit where the study was being conducted. The combination of both roles was not an easy task given the ethical issues and the fact that the availability of the professional/researcher could be called into question. However, the development of the intervention protocol and the preparation prior to the implementation of the BIs were critical to achieve the objectives set out.

The fact that this was a pre-experimental study, with one-group pretest-posttest design, without a control group, posed several threats to internal validity, as no other variables to which the sampled participants had been exposed to and that could increase the risk levels of alcohol consumption were controlled for. Also, the lack of a control group (not receiving BIs) did not allow us to confirm that the positive evolution was indeed a result of BIs, and not a result of other factors.

The chosen sampling method - nonprobability sampling - was also a limitation as the sample included users who were present at the time of data collection and respective intervention. However, only 24 respondents were part of the sample, which may cause bias and limit the representativeness of the target population.

Finally, as regards the final assessment, although the BIs were developed according to the protocol and had a 5-month follow-up, subsequent assessments are needed to check if the effects of BIs continued after that period.

\section{Conclusion}

This study shows that the users of this sample have high levels of risk of alcohol consumption, and that the BIs developed by a qualified nurse reduce the levels of risk of alcohol consumption in users undergoing methadone maintenance treatment programs. These changes in drinking behaviours and the improvement of the general health status can contribute to increasing the users' adherence to methadone maintenance treatment programs.

The training of healthcare professionals, especially nurses, for the early detection of hazardous drinking, implementation of BIs to reduce alcohol abuse, monitoring, and referral should be a priority in basic and specialised education.

Despite the abovementioned limitations, this study is an important contribution to the recognition of the effectiveness of BIs in reducing the levels of risk of alcohol consumption in users undergoing methadone maintenance treatment programs.

\section{References}

Babor, T. F., \& Higgins-Biddle, J. C. (2001). Brief intervention: For hazardous and harmful drinking ( $2^{\mathrm{a}}$ ed.). Genebra, Switzerland: World Health Organization.

Balsa, C., Vital, C., Urbano, C., \& Pascueiro, L. (2008). II inquérito nacional ao consumo de substâncias psicoactivas na população portuguesa: 2007. Lisboa, Portugal: Serviço de Intervenção nos Comportamentos Aditivos e nas Dependências.

Barroso, T., Barbosa A., \& Mendes, A. (2006). Programas de prevenção do consumo de álcool em jovens estudantes: Revisão sistemática. Referência, 2(3), 33-44.

Barroso, T., Rosa, N. R., Jorge, F. M., \& Gonçalves, C. S. (2012). Drinking among adolescents and young adults: Outcome of brief intervention. Alcoholism, 36( 9), $131 \mathrm{~A}$.

Caputo, F., Addolorate, G., Domenical, M., Mosti, A., Viaggi, M., Trevisani, F., ... Stefanini, G. F. (2002). Short-term methadone administration reduces alcohol consumption in non-alcoholic heroin addicts. Alcohol \& Alcoholism, 37(2), 164-168.

El-Bassel, N., Schilling, R. F., Turnbull, J. E., \& Kuo-Hsien, S. (1993). Correlates of alcohol use among methadone patients. Alcoholism: Clinical and Experimental Research, 17(3), 681-686.

Furtado, E. F., \& Marques, A. C. (2004). Brief interventions for alcohol related problems. Revista Brasileira de Psiquiatria, 26, 28-32.

Gossop, M., Marsden, J., \& Stewart, D. (2002). Dual dependence: Assessment of dependence upon alcohol and illicit drugs, and the relationship of alcohol dependence among drug misusers to patterns of drinking, illicit drug use and health problems. Society for the Study of Addiction to Alcobol and Other Drugs: Addiction, 97, 169-179. 
Henriques, A. B., \& Paixão, R. (2009). Padrões de consumo de álcool em programas de substituição de opiáceos. Toxicodependências, 15(3), 39-49.

Instituto da Droga e da Toxicodependencia, I.P. (2012). Relatório Anual de 2011: A situação do país em matéria de drogas e toxicodependências. Loures, Portugal: Autor.

Moussas, G., Fanouraki, I., Pachi, A., Asomatou, A., Drylli, O., Paschalakis, G., ... Malliori, M. (2015). Comorbid psychopathology and alcohol use patterns among methadone maintenance treatment patients. Journal of addiction. Retrieved from http://www.hindawi.com/ journals/jad/2015/197652/abs/

Ottomanelli, G. (1998). Methadone Patients and Alcohol Abuse. Journal of Substance Abuse Treatment, 16(2),113-121.

Patrício, L. (2009). Tratamento da dependência de beroína: A manutenção opióide. Lisboa, Portugal, Psiquiatria e Medicina.

Ribeiro, C. (2014). Medicina Geral e Familiar e Abordagem do Consumo de Álcool: Deteção e Intervenções Breves no âmbito dos Cuidados de Saúde Primários. Lisboa, Portugal,
Serviço de Intervenção nos Comportamentos Aditivos e nas Dependências.

Schaus, J. F., Sole, M. L., McCoy, T. P., Mullett, N., \& O'Brien, M. C. (2009). Alcohol screening and brief intervention in a college student health center: A randomized control trial. Journal of Studies on Alcobol and Drugs, 16, 131-141.

Segatto, M. L., Pinsky, I., Laranjera, R., Rezende, F. F., \& Vilela, T. R. (2007). Triagem e intervenção breve em pacientes alcoolizados atendidos na emergência: Perspectivas e desafios. Caderno de Saúde Publica, 33(8), 1753-1762.

Seigers, K., \& Carey B. (2010). Screening and brief interventions of alcohol use in college health center: A review. Journal of American College Health,59(3),151-158.

Serviço de Intervenção nos Comportamentos Aditivos e nas Dependências. (2013) Plano nacional para redução dos comportamentos aditivos: PNRCAD-2013-2020. Lisboa, Portugal: Autor.

World Health Organization (2014). Global status report on alcohol and health. Genebra, Switzerland: Author. 